\title{
Viewpoint: service marketing research priorities
}

\author{
Christian Grönroos \\ Department of Service and Relationship Marketing, Hanken School of Economics, Helsinki, Finland
}

\begin{abstract}
Purpose - This paper aims to emphasize two key research priorities central to the domain of service marketing.

Design/methodology/approach - Reflections based on conceptual analysis of the current level of knowledge of service as an offering and of the nature of service marketing in the literature.

Findings - It is observed that research into marketing and into service as an object of marketing, or as an offering, has been neglected for two decades and more. It is also shown that to restore its credibility, marketing needs to be reinvented. Furthermore, the point is made that if a proper understanding of service as an object of, for example, innovation, design, branding and development is lacking, or even only implicitly present, valid research into those and other important topics is at risk.

Research limitations/implications - This paper discusses two neglected topics within the domain of service research. Other important areas of future research are not covered. However, the paper offers directions for service marketing research fundamental to the development of the discipline.

Originality/value - In earlier discussions of service and service marketing research priorities, the observation that service and marketing are neglected topics that need to be studied and further developed has not been made. The paper emphasizes that service marketing research also needs to return to its roots and suggests possible directions for future research.
\end{abstract}

Keywords Service delivery, Customer participation, Service design, Service marketing research priorities, Service marketing, Service, Marketing

Paper type Viewpoint

The purpose of this paper is to discuss two neglected but central topics within the domain of service marketing that, in my view, need urgent attention in service research. Because these topics are of such fundamental importance to the understanding of service marketing, I consider them just as important, if not more important, as any of the significant service research priorities that have been suggested in the literature. These topics are service and marketing. First, I discuss the research into these topics that exist, and then I suggest directions that, in my view, would enable further fruitful research into these topics.

\section{State of current knowledge}

Service innovation and design, transformative service research, service branding, accountability, service logic, digitalization and other topics have been suggested as important research priorities (Ostrom et al., 2015). These are, of course, central research topics in the field of service marketing today. However, there are two more fundamental aspects of service marketing that have been neglected in service marketing research and where solid service-focused models are missing, namely, service and marketing.

Rathmell (1974, p. 7) made the following comment about service marketing research: "definitions, classifications, data,

The current issue and full text archive of this journal is available on Emerald Insight at: https://www.emerald.com/insight/0887-6045.htm

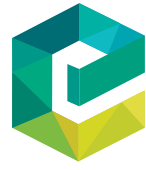

Journal of Services Marketing

34/3 (2020) 291-298

Emerald Publishing Limited [ISSN 0887-6045]

[DOI 10.1108/JSM-08-2019-0306] and concepts are lacking, noncomparable, or unreal from a marketing perspective." He continued,

[...] moreover as one attempts to integrate marketing terms, concepts, and practices with firms, institutions and professions having their own traditions, customs, and practices which are quite foreign to conventional marketing (and much older), the linkage appears awkward and even improper (p. 7).

He also observed that service firms do not have one contact point with their customers covered by conventional marketing, but two - namely, marketing and production. The interactions between buyers/consumers and sellers/service providers that take place in the latter contact point are relevant to marketing in service firms (p. 6). Three years after Rathmell, Shostack (1977, p. 73) observed that:

[...] merely adopting product marketing's labels does not resolve the question of whether product marketing can be overlaid on service businesses. Can corporate banking really be marketed according to the same basic blueprint that made Tide a success?

Her conclusion was that "new concepts are necessary if service marketing is to succeed" (p. 73). My question is, how far has research into service marketing reached since these early days of

(C) Christian Grönroos. Published by Emerald Publishing Limited. This article is published under the Creative Commons Attribution (CC BY 4.0) licence. Anyone may reproduce, distribute, translate and create derivative works of this article (for both commercial \& non-commercial purposes), subject to full attribution to the original publication and authors. The full terms of this licence may be seen at http://creativecommons.org/licences/ by/4.0/legalcode

Received 20 August 2019

Revised 8 January 2020

9 January 2020

Accepted 11 January 2020 
modern service research? The sad answer is that it has not reached very far.

In a conference paper presented at one of the American Marketing Association's service marketing conferences in the 1980s, I made the rather obvious remark about the development of service as an offering that "one of the most essential cornerstones in developing something is a thorough understanding of the phenomenon to be developed" (Grönroos, 1987, p. 81). In an article published six years later together with Hans Åke Sand, Chief Executive Officer of an innovative and successful car rental enterprise, we noted that "there is no generally accepted conceptual model [...] of services as products, i.e. as objects to be developed, produced and marketed" (Grönroos and Sand, 1993, p. 45). Again, my question is, how far has research into service as an object of marketing or as an offering reached since those early days of service research? Again, the answer is equally saddening. During the past 15 years, service as a phenomenon has been discussed as part of the research into service as logic (Vargo and Lusch, 2004; Grönroos, 2011). Recently, I have defined service as a phenomenon as providing help to another person's or organization's relevant processes in a way valuable to this person or organization (Grönroos, 2019). However, since the 1980s and 1990s, very little has been published on service as an offering - that is, as an object to be innovated, developed, designed, produced, delivered and marketed. Studies on innovation, design and development of services are abundant, but the object of such research is seldom discussed and specified explicitly.

As marketing has been a driving force of modern service research and its dominating subareas, the conceptual development of service marketing should be a central research priority. As marketing of services cannot be understood conceptually without an understanding of what service as an object of marketing consists of, conceptual development of service as an offering or an object to be marketed should be another self-evident research priority in service research. Service and marketing are so central to service research that I will focus on them in the present article. First, marketing will be discussed and then service.

\section{There were attempts to develop service marketing models, but what happened?}

In the early days of modern service research, several conceptual models of service marketing were developed. In the 1970s and early 1980s, four models, in particular, were published: Eiglier and Langeard's servuction model (Eiglier and Langeard, 1975; Langeard and Eiglier, 1987), Shostack's molecular model (Shostack, 1977), Grönroos's interactive marketing model (Grönroos, 1978; Grönroos, 1982) and Booms and Bitner's 7P model (Booms and Bitner, 1982). In addition, Berry (1983) introduced the idea of relationship marketing, emphasizing the long-term timeframe of service marketing. Following the classification provided in Berry and Parasuraman's (1993) analysis of the service marketing field, the servuction model represents the French school, the interactive marketing the Nordic school, and the $7 \mathrm{P}$ model the American school. of service marketing. The molecular model includes elements of both the first and second schools. These models are genuinely geared toward characteristics of service firms, predominantly the process nature of services and the impact of interactions between providers and customers, but they are based on somewhat different approaches. The servuction model is based on resources active in the service (production) process; the interactive marketing model is geared toward Rathmell's observation that both conventional marketing and production processes influence customers and thus have marketing implications and take, at least partly, a process approach to marketing. The 7P model takes conventional marketing's four decision-making areas as the starting point and adds three more Ps representing decision-making areas relevant to service firms. Basically, this model is a decision category model, but it includes process as one of the new service-specific decisionmaking categories. The molecular model emphasizes that to market services successfully, a number of other resources and processes influencing customers have to be taken into account in addition to conventional marketing activities. In various ways, all these models go beyond conventional models by including aspects related to service production and interactions between customers and service providers. As shown in Berry and Parasuraman (1993), there were a large number of publications on service marketing in the 1980s and 1990s (Zeithaml et al., 1985; to mention but one), but the field was really not developed further. Then service research turned to other topics.

\section{Enter service quality, exit service marketing}

Following my, and to a larger extent Berry, Parasuraman and Zeithaml's articles on service quality in the 1980s (Grönroos, 1982, 1984; Parasuraman, Zeithaml and Berry, 1985; Zeithaml et al., 1988), an interest in service quality grew almost exponentially among service researchers. At the same time as this explosion of service quality studies took place in the late 1980s and 1990s (Cronin and Taylor, 1994; Boulding et al., 1993; Teas, 1993; Brady and Cronin, 2001), studies of service marketing more or less died out. Why did this happen? In my view, service marketing requires genuinely new approaches, which did not fit the conventional and dominating marketing mix management paradigm and kept researchers from continuing the studies of marketing in service firms. The conventional paradigm offered a too-heavy straitjacket to allow for boundary-spanning research approaches. However, service quality enabled researchers to still study how service firms could approach their customers to make them satisfied - a theme central to marketing - without having to place it in the marketing domain and challenge established marketing "truths." Studies of service quality became a surrogate for studying marketing. Without putting it into a marketing framework and without having to move marketing as marketing into inconvenient directions geared to the characteristics of service, the production and interactionrelated aspects could still be studied, but in a service quality domain. Whether this happened consciously or unconsciously can be debated.

As far as my early publications (Grönroos, 1982, 1984) labeled "service quality" were concerned, the goal was never to initiate research into the quality of services. Everything was a mistake (Grönroos, 2001). In reality, I was interested in how 
customers perceive service as an offering or object of consumption. I was looking at the features of service offerings that customers perceived and appreciated as a starting point for further research on how to conceptualize service as an object of production, delivery and marketing. I just happened to choose the label "perceived service quality" for such perceptions. In hindsight, I should have called it "perceived service features" instead. Once the fast-spreading interest in service quality research occurred (and I was, of course, not its only initiator), it was too late to stop it. And service quality research did offer new insights into quality; for example, the observation that quality is not what firms produce and offer, but what customers perceive.

In conclusion, instead of exploring the nature of marketing in service firms and developing models of service marketing further, the service research community devoted itself to studying other service-related topics. Service quality was especially the topic of interest, as I understand it, as a surrogate for studying marketing issues directly, where researchers did not have to challenge the steadfast grip of the conventional marketing mix management view. As I said before, perceived service quality relates directly to the aspects of the servuction, molecular, interactive marketing and $7 \mathrm{P}$ models unique to service.

When the interest in service quality faded away toward the end of the 1990s, with the new focus on service as a perspective or logic on business and marketing, value and how value is created and co-created became key topics in service research (Vargo and Lusch, 2004; Grönroos, 2011). However, the same thing as with service quality happened. This field of research exploded and, although it has been claimed that it is about a new logic for marketing, attempts to conceptualize marketing are largely lacking. At the same time, other topics of importance, such as design, innovation, customer experience, customer engagement, transformative service, service branding and digitalization have also drawn the attention of the research community. In none of these areas has conceptualizing marketing been of central interest.

\section{How serious is this?}

An absolute key research priority in service research is to finally continue the research into service marketing that took place in the early days of modern research into the service field. Unless a valid and acceptable model (or models) of marketing relevant to service is developed and found useful, none of the advances made in designing, innovating and digitalizing services, to mention just a few topics, can be fully used, or used at all. Marketing has to reinvent itself. Its credibility and use in firms has been in decline for a long time. In a section of a 2005 issue of the fournal of Marketing labeled "Marketing Renaissance," supposedly devoted to reinventing marketing, Stephen Brown reported a study among top executives of major serviceoriented firms associated with the Center for Services Leadership at Arizona State University. He wrote, "notably, none of the executives mentioned marketing as being responsible for the customer." The executives indicated that "marketing and sales often have a major role in making promises to customers and in generating new business. However, the keeping of promises and building customer loyalty is typically considered the responsibility of others in the enterprise"
(Brown, 2005, p. 3, italics added). In the same section, these observations are reinforced by Sheth and Sisodia (2005, p. 11), who note that "many strategically important aspects of marketing [...] are being taken away by other functions in the organization." The only other important observations for reinventing marketing from the 12 papers in this marketing renaissance section, in my view, are the general conclusion that there is "[a] weak linkage between marketing scholarship and marketing practice" (Brown, 2005, p. 3), and Sheth and Sisodia's(2005, p. 12) concluding remark:

Can marketing's reputation be redeemed? Not unless it resolves the fundamental contradiction at its core: Marketing claims to be about representing the customer to the company, but it remains mostly about representing the company to the customer, using every trick in its bag to make customers behave in the company's best interests.

Since then, the development of digitalization has strengthened the position of the customers, but the conventional marketing models have had difficulties handling this.

The observations presented above should be taken seriously. Marketers do not honestly have customers' best interests in mind, in parallel with the firm's interest. Moreover, employees other than the marketers are responsible for keeping customers and, therefore, for making customers feel satisfied with how the firm serves them and also for their continued patronage to the firm. For the research community, it should be a wake-up call drawing researchers' interest to study how marketing can be reinvented to fit today's customer communities and business practices. So far, neither service researchers nor marketing scholars, in general, have reacted. As a consequence, marketing continuously becomes less relevant to firms and top management, and only tactical, if anything, and marketing as an academic discipline loses credibility as part of the management and business administration field.

\section{Reinventing marketing through promise theory}

Keeping Sheth and Sisodia's criticism of contemporary marketing as not representing the customers to the firm in mind, the ultimate goal of marketing should be to make the firm relevant to its customers (Grönroos, 2015; italics added). Conceptualizing marketing should be founded on this requirement. Furthermore, marketing is a process that includes many elements, such as creating interest in the firm and its offerings, making customers who have bought the offerings feel satisfied with them and creating enduring relationships with customers. In a service context, the offering, the service that is consumed, is a process and to a varying degree, it emerges in interactions between the service provider and the customer. Moreover, as emphasized by customer-dominant logic, the customer puts offerings into their customer ecosystems and, based on that, they determine the importance and value to them of such offerings (Heinonen and Strandvik, 2015). All this needs to be incorporated in attempts to conceptualize service marketing.

For me, promise theory, already introduced in marketing in the 1980s by Calonius (1986), offers solid ground to build upon. It pinpoints and elaborates on the very problem of marketing demonstrated in Stephen Brown's contribution to the marketing renaissance discussion, namely, that marketing has reverted to promise-making and lost control of actions and processes that secure customer satisfaction and loyalty. As Bitner (1995, p. 246), inspired by Calonius, proposed in the 
title of a promise-related article, "it is all about promises." As Calonius formulated promise theory as a foundation of market behavior:

[a] promise is a more or less explicitly expressed conditional declaration of assurance made to another party, or to oneself, with respect to the future, stating that one will do [...] some specific act. [...] The action or intentional activity called forth by a promise [...] will occur with some probability in the near or more distant future (Calonius, 2006, p. 422).

This simply means that marketers should make promises to their customers that can be kept and then keep these promises, thereby fulfilling the expectations among customers created by the promises made. If such promises relate well to the customers' life situations, activities and needs - in other words, to their customer ecosystems - this behavior should make the firm relevant to them and marketing should achieve its ultimate goal.

Developing marketing models based on promise theory requires that marketing is conceptualized as a promise management process, where making and keeping promises are integrated. Instead of being a rather static marketing conceptualization based on decision categories, such as the $4 \mathrm{P}$ model, this would be a dynamic marketing-as-a-process conceptualization. However, the promise-making/promisekeeping dichotomy is not new to marketing. The 4P model includes the product variable, which is clearly thought to fulfill the promise-keeping requirement. The problem is that the promise-keeping capacity of the product variable is only inherent in the model, and not explicitly emphasized or even pointed out. Furthermore, as the product is frequently given to the marketers, the promotion, price and place variables of the model take over, and they are all geared toward promisemaking. As a conclusion, marketing mentally and factually becomes a promise-making issue, where the product is thought to keep promises made more or less automatically.

In a service context, this does not function, because in service there are no products as pre-produced, tangible artifacts. Service is a process-based business (Edvardsson et al., 2005), where promises are made of processes taking place in the future and promises are kept through how well such processes function to a smaller or larger extent in interactions with the customers. This changes things immensely. Promise-keeping cannot be taken for granted anymore. For the firm's marketing, keeping a promise does not happen automatically, as conventional models of marketing assume. The process that the customers experience must be managed in a customer-focused manner - that is, in a way that has the marketing effect of making the customers satisfied and willing to engage with the firm in the future as well. Moreover, what is "the firm's marketing?" We are used to thinking of marketing as a separate function alongside other business functions, often managed by a marketing department of full-time marketers. As the process of keeping promises is outside the immediate responsibility and control of those in the firm who make promises about this process - that is, the full-time marketers - marketing as promise-keeping extends marketing beyond those who, according to conventional marketing models, are considered the marketers.

\section{Conceptualizing service marketing as promise management}

Marketing as promise management means that three separate processes need to be studied and developed, namely, a process of promise-making, a process of promise-keeping, and, in addition, a process of promise-enabling. In conventional marketing, relying on a marketing department of full-time marketers, those responsible for marketing activities are thought to be marketing professionals. However, the service or frontline employees interacting with customers in the service (production) process are employed in other non-marketing business functions. Primarily their job is to make sure that the process functions well from a technical point of view. However, as part-time marketers, to use a term introduced by Gummesson (1991), they fulfill a key marketing function when interacting with customers. As Gummesson (1995) also notes, there normally are many more part-time marketers than full-time marketers, and they meet customers at the very point of service production and consumption. In creating customer satisfaction and loyalty, and in generating resales, their role is critical. To make sure that the part-time marketers are prepared and willing to fulfill their role in the promise-keeping part of the total marketing process, activities and processes labeled internal marketing (Grönroos, 2015) in the service literature are needed. Through internal marketing, it is assured that promises can be made and kept successfully, such that customers buy and become satisfied with what they have bought. This is promiseenabling.

In an article published in 2006, I draw guidelines for the development of marketing and suggest an overarching marketing definition based on the promise management approach:

Marketing is a customer focus that permeates organizational functions and processes and is geared towards making promises through value proposition, enabling the fulfilment of individual expectations created by such promises, and fulfilling such expectations through support to customers' valuegenerating processes, thereby supporting value creation in the firm's as well as its customers' and other stakeholders' processes (Grönroos, 2006, p. 407).

These guidelines point out that, when conceptualizing service marketing, one needs to distinguish between those resources and activities that take responsibility for making promises and those that take responsibility for keeping promises. The former resources are probably mainly full-time marketers, whereas the latter are part-time marketers as well as other resources and systems - physical and digital - that the customers interact with or are exposed to in some other way. The servuction, molecular, interactive marketing and $7 \mathrm{P}$ models of the early days of service research include such resources as well as processes active in such interactions in various ways. In addition, the role of the customers themselves as a resource in service marketing is emphasized in some of these models and in early service research. Furthermore, the promise management definition emphasizes that promises made create individual expectations among customers and that those responsible for marketing in the promise-keeping phase must be prepared to take this into account when interacting with customers. This is part of internal marketing as the promise-enabling process.

The promise management guideline and overarching definition offer many opportunities for service researchers to conceptualize service marketing and develop more detailed models of service marketing and, for example, of the various sub-processes of promise management. 


\section{What is "the firm's marketing"?}

Earlier, I raised the question of what is meant by "the firm's marketing." What is included in the marketing process of a firm? Conventional marketing thought assumes that marketing is a separate function frequently managed by a marketing department. In the literature, "marketing department" is often used as a synonym of "marketing function." However, when the product is replaced by the service process, and frontline service employees, who are part of other functions in the firm, take on the role of part-time marketers, marketing cannot be viewed in the traditional, rather simplistic manner anymore. As Wilkie (2005, p. 9) concluded his analysis in the discussion of the renaissance of marketing, "in brief, we need a larger conception of marketing." Furthermore, marketing cannot be organized in traditional ways. As the promise management guideline and definition imply, because frontline employees/ part-time marketers belong to several functions, marketing permeates several organizational functions. An obvious conclusion is that marketing can only be partly organized (Grönroos, 2015). The promise-making process can in most cases be organized in a separate department, but the promisekeeping process is spread throughout the organization. Therefore, it cannot be organized in any conventional structures. Instead, in the context of promise-keeping, marketing must be instilled as a customer-focused mindset (Grönroos, 2015). Instilling this mindset demands internal marketing efforts. How to ensure that marketing functions well in the promise-keeping sub-process without organizing it offers an abundance of important and interesting research opportunities. However, this requires that researchers move out of their comfort zone of studying marketing issues through traditional lenses. As Webster (2005, p. 6) formulates it, to develop marketing "we must tolerate work that bursts through and redefines the currently accepted boundaries of our intellectual domain."

\section{What about the term "marketing"?}

When developing service marketing, a word about the term "marketing" is warranted. When people outside of marketing's traditional boundaries become part of marketing, and when business functions other than marketing become part of the firm's total marketing process, it becomes doubtful whether "marketing" signifies the phenomenon we are talking about very accurately. It is a matter of something much larger than getting out into the market. Employees who have different background and training easily find marketing inherently unacceptable and resist being part of it. In 1999, I suggested that dropping the term may serve the introduction of marketing into service firms better than using it (Grönroos, 1999). It is also a matter of marketing's credibility among employees, customers and top management. Twenty years later, this suggestion still seems to be too controversial to be picked up in any serious research into marketing. However, in the discussion of a renaissance for marketing, Sheth and Sisodia (2005, p. 12) make the point that "the word 'marketing' has lost so much credibility that companies would be better off using the designation of chief customer officer rather than CMO." Clearly, they too find the term "marketing" problematic.
In conclusion, key research priorities for future service research that relate to the marketing domain include the nature, scope, boundaries and content of service marketing, how to organize for service marketing and even whether "marketing" is a term that enables the successful introduction of service marketing in firms or whether a different term is needed.

\section{What should be marketed is also missing in service research: the service offering}

Product is a key marketing variable in the conventional $4 \mathrm{P}$ model. Without an understanding of the product to be marketed, successful product marketing outcomes cannot be expected. This is, of course, also true for service marketing. How can the object to be marketed be understood and conceptualized in the context of services? This is critical for other research areas besides marketing within the service domain as well. For example, innovation, design, branding and transformative service have drawn extensive attention from service researchers. The fournal of Service Research has published special issues on service design (February 2008) and transformative service research (August 2015). The articles published in these issues develop new thoughts, concepts and models largely based on an understanding of customers and their processes, which, of course, is important. However, what also is important is an explicit understanding of what constitutes the service that is innovated, designed and branded, and which the customers purchase and consume. Models or conceptualizations or even discussions of this are lacking. In an overview article of service innovation, Helkkula et al. (2018) define four archetypes of innovation in the extant research, namely, output-based, process-based, experiential and systemic archetypes. Here, too, service as an object of innovation is not explicitly present.

Given the amount of research on the many subfields of service that has been published, it is, in my view, worrying that there is no clear model or models of service as an object or offering to be produced, marketed and consumed. This object is a process (Edvardsson et al., 2005), and as a phenomenon, it is something that aims to help, for example, customers to achieve goals that are valuable to them (Grönroos, 2019). However, what features or elements constitute this object? In the following paragraphs, I use the term "service offering" for such an object.

In the 1970s and 1980s, some publications on service included observations about service offerings. It was noted that they included two types of services - namely, core and auxiliary services (Normann, 1984) - as part of a service package (Sasser et al., 1978; Normann, 1984). In the context of their servuction model, Langeard and Eiglier (1987) discuss an offering system. In the context of service development, Edvardsson (1996) made the point that customers have what he termed primary needs, which are fulfilled by a set of core and auxiliary service elements - such as guest rooms, booking, check-in service, and breakfast service in a hotel context - and secondary needs, which relate to how these services function as processes. The words "primary" and "secondary" are not used to indicate any difference in nature or importance; he emphasized that both types of customer needs have to be acknowledged. 
Edvardsson's model was partly based on a conference paper from 1987 (Grönroos, 1987), where I pointed out the need to distinguish between two layers in a service offering, namely, a basic package of service elements and an augmentation of this package. This augmentation makes the service process part of the service offering. In this model, the augmentation includes three variables: accessibility of the service; interactions between the customer and the many service provider resources; and finally the customer's ability to participate in the service process, termed customer participation (Grönroos, 1987, 2015). Later, in the context of digital services, together with Kristina Heinonen and other colleagues (Grönroos et al., 2000), we suggested that the accessibility and interaction variables merge into one information variable. In the same conference paper, I also emphasized that auxiliary services added to a core service (lodging, in the hotel example) in a service package are of a different nature and fulfill different purposes. For example, booking and check-in services in the hotel example are mandatory services. If they are missing or not accessible, the customer cannot use the core service. However, breakfast service is not mandatory in the same sense. The purpose of such a service is to enhance the service offering, whereas the purpose of the former types of services is to enable the use of the core service. Hence, for the understanding of the service package, it is important to distinguish between the core service, offeringenabling services and offering-enhancing services (Grönroos, 1987; terminology as in Grönroos, 2015).

\section{Conceptualizing service as an object or offering}

When developing a model of service offering - that is, of services as objects for production, marketing and consumption - a critical starting point is that services are not product-like objects but processes that lead to an outcome. As demonstrated by the perceived service quality model (Grönroos, 1984), both the outcome and the process influence the customers' perceptions. Furthermore, the distinction between customers' primary needs and secondary needs, as suggested by Edvardsson (1996), should be taken into account. To fulfill primary needs, the service model must include service elements, such as guest rooms and booking, check-in and breakfast services in the hotel example used earlier. To fulfill secondary needs, the service model must also include process-related aspects of the service, which guarantee that the service elements function in a customerfocused manner. The service elements form the service package, but this package is not the service as an object or offering. They only make sure that the service's intended outcome is achieved. In perceived service quality terms (Grönroos, 1984), they ensure that the technical outcome quality can be delivered. The role of the process-related aspects is to guarantee that the service elements of the service package also function in a desired manner, such that a satisfying service emerges. In perceived service quality terms, they ensure that the functional process quality requirement is achieved. When conceptualizing services, however it is done, both service package elements and service process-related aspects must be included.

When developing the elements of the service package, it is also essential to observe that they may fulfill different purposes, such as mandatory elements enabling the use of the core service and optional elements enhancing the perception of the service. Most service elements can be both enabling and enhancing. To use a car rental example (Grönroos and Sand, 1993), the core service is transportation by a rented vehicle. Access to a wanted vehicle is a purely enabling service element, whereas, for example, the reservation system, information about terms and conditions, vehicle return system and payment system can be both enabling and enhancing service elements. Complaints handling and service recovery are examples of purely enhancing service elements.

In my 1987 model, I proposed that accessibility, interaction and customer participation variables are used to augment the service package and cover the process-related aspect of services (Grönroos, 1987); and in 2000 study, my colleagues and I suggested that information and customer participation variables can be used to conceptualize the augmentation of digital services (Grönroos et al., 2000). These are only research-based examples from the literature of ways of conceptualizing the service package and of augmenting the elements of this package. This "augmented service offering" approach offers an abundance of opportunities to further conceptualize service as an offering or object. However, regardless of how models of services as objects or offerings are conceptualized, both service elements and the process-related augmentation of such elements need to be taken into account. Otherwise, the model will not be conceptualized in a way that meets the customers' view of what constitutes services.

\section{Concluding remarks}

In the present article, I have made the point that marketing and service as objects of marketing or offerings are neglected research topics within the domain of service marketing and that these topics should be highly prioritized in service research. This does not mean that other suggested research priorities are less important - on the contrary. However, the need to study service and marketing again has not been voiced for decades. Therefore, it is essential to draw the service research community's attention to these topics very fundamental to our field and to emphasize the urgent need to study them. Moreover, service and marketing form the very foundation of our domain, and without proper understanding of them, the development of other current and future service topics may generate less valid results.

\section{References}

Berry, L.L. (1983), "Relationship marketing”, in Berry, L.L., Shostack, G.L. and Upah, G. (Eds), Emerging Perspectives in Services Marketing, American Marketing Association, Chicago, IL, pp. 25-28.

Berry, L.L. and Parasuraman, A. (1993), "Building a new academic field - the case of services marketing", fournal of Retailing, Vol. 69 No. 1, pp. 13-60.

Bitner, M.J. (1995), "Building service relationships: it's all about promises", Fournal of the Academy of Marketing Science, Vol. 23 No. 4, pp. 246-251.

Booms, B.H. and Bitner, M.J. (1982), "Marketing structures and organization structures for service firms", in Donelly, 
J.H. and George, W.R. (Eds), Marketing of Services, American Marketing Association, Chicago, IL, pp. 47-51.

Boulding, W., Kaira, A., Staelin, R. and Zeithaml, V.A. (1993), “A dynamic process model of service quality: from expectations to behavioural intentions", fournal of Marketing Research, Vol. 30 No. 1, pp. 7-27.

Brown, S.W. (2005), "When executives speak, we should listen and act differently", fournal of Marketing, Vol. 69, pp. 1-4.

Brady, M.K. and Cronin, J.J. Jr. (2001), "Some thoughts on conceptualizing perceived service quality", fournal of Marketing, Vol. 65 No. 3, pp. 34-49.

Calonius, H. (1986), "A market behaviour framework", in Möller, K. and Paltschik, K. (Eds), Proceedings from the $X V$ Annual Conference of the European Marketing Academy, Helsinki School of Economics/Hanken School of Economics, Finland, pp. 515-524.

Calonius, H. (2006), "A market behaviour framework", Marketing Theory, Vol. 6 No. 4, pp. 419-428.

Cronin, J.J., Jr. and Taylor, S.A. (1994), "SERVPERF versus SERVQUAL: reconciling performance-based and perceptions-minus-expectations measurement of service quality", fournal of Marketing, Vol. 58 No. 1, pp. 125-131.

Edvardsson, B. (1996), "Tjänsteutveckling med inbyggd kvalitet (in Swedish: Quality-based service development)", Research report 96:9, Centre for Service Research, University of Karlstad.

Edvardsson, B., Gustafsson, A. and Roos, I. (2005), "Service portraits in service research: a critical review through the lens of the customer", International fournal of Service Industry Management, Vol. 16 No. 1, pp. 107-121.

Eiglier, P. and Langeard, E. (1975), "Une approche nouvelle du marketing des services", Revue Francaise de Gestion, Vol. 1, pp. 97-114.

Grönroos, C. (1978), “A service-orientated model of the marketing of services", European fournal of Marketing, Vol. 12 No. 8, pp. 588-601.

Grönroos, C. (1982), “An applied service marketing theory”, European fournal of Marketing, Vol. 16 No. 7, pp. 30-41.

Grönroos, C. (1984), “A service quality model and its marketing implications”, European fournal of Marketing, Vol. 18 No. 4, pp. 36-44.

Grönroos, C. (1987), "Developing the service offering - a source of competitive advantage", in Surprenant, C. (Ed.), Add Value to Your Service. The Key to Success, American Marketing Association, Chicago, IL, pp. 81-85.

Grönroos, C. (1999), "Relationship marketing: challenges for the organization", Fournal of Business Research, Vol. 46 No. 3, pp. 327-335.

Grönroos, C. (2001), "The perceived service quality concept a mistake", Managing Service Quality: An International Fournal, Vol. 11 No. 3, pp. 150-152.

Grönroos, C. (2006), “On defining marketing: finding a new roadmap for marketing”, Marketing Theory, Vol. 6 No. 4, pp. 395-417.

Grönroos, C. (2011), "Value co-creation in service logic: a critical analysis", Marketing Theory, Vol. 11 No. 3, pp. 279-301.

Grönroos, C. (2015), Service Management and Marketing: Managing the Service Profit Logic, 4th edition: John Wiley \& Co, Chichester.
Grönroos, C. (2019), "Reforming public service: does service logic have anything to offer?", Public Management Review, Vol. 21 No. 5, pp. 775-788.

Grönroos, C. and Sand, H.A. (1993), "A winning service offer in car rental", Management Decision, Vol. 31 No. 1, pp. 45-51.

Grönroos, C., Heinonen, F., Isoniemi, K. and Lindholm, M. (2000), "The NetOffer model: a case example from the virtual marketspace", Management Decision, Vol. 38 No. 4, pp. 243-252.

Gummesson, E. (1991), "Marketing revisited: the crucial role of the part-time marketers", European fournal of Marketing, Vol. 25 No. 2, pp. 60-67.

Gummesson, E. (1995), "Relationship marketing: its role in the service economy", in Glynn, W.J. and Barnes, J.G. (Eds), Understanding Services Management, John Wiley \& Co, New York, NY, pp. 244-268.

Heinonen, K. and Strandvik, T. (2015), "Customer-dominant logic: foundations and implications", fournal of Services Marketing, Vol. 29 Nos 6/7, pp. 472-484.

Helkkula, A., Kowalkowski, C. and Trondvoll, B. (2018), "Archetypes of service innovation: implications for value cocreation", fournal of Service Research, Vol. 21 No. 3.

Langeard, E. and Eiglier, P. (1987), Servuction: Le Marketing des Services, Wiley, Paris.

Normann, R. (1984), Service Management: Strategy and Leadership in Service Businesses, John Wiley \& Sons, New York, NY.

Ostrom, A.L., Parasuraman, A., Bowen, D.E., Patricio, L. and Voss, C.A. (2015), "Service research priorities in a rapidly changing context”, fournal of Service Research, Vol. 18 No. 2, pp. 127-159.

Parasuraman, A., Zeithaml, V.A. and Berry, L.L. (1985), “A conceptual model of service quality and its implications for future research", fournal of Marketing, Vol. 49 No. 4, pp. 41-50.

Rathmell, J.M. (1974), Marketing in the Service Sector, Wintrop Publishers, Cambridge, MA.

Sasser, W.E., Olsen, R.P. and Wyckoff, D.D. (1978), Management of Service Operations: Text and Cases, Allyn and Bacon, Boston, MA.

Sheth, J.N. and Sisodia, R.S. (2005), "Does marketing need reform?”, fournal of Marketing, Vol. 69, pp. 10-12.

Shostack, G.L. (1977), "Breaking free from product marketing", fournal of Marketing, Vol. 41 No. 2, pp. 73-80.

Teas, K.R. (1993), "Expectations as a comparison standard in measuring service quality", fournal of Marketing, Vol. 58 No. 1, pp. 132-139.

Vargo, S.L. and Lusch, R.F. (2004), "Evolving to a new dominant logic for marketing", fournal of Marketing, Vol. 68 No. 1, pp. 1-17.

Webster, F.E. Jr. (2005), "Back to the future: integrating marketing as tactics, strategy, and organizational culture", Fournal of Marketing, Vol. 69, pp. 4-5.

Wilkie, W.L. (2005), "Needed: a larger sense of marketing and scholarship", fournal of Marketing, Vol. 69, pp. 8-10.

Zeithaml, V.A., Berry, L.L. and Parasuraman, A. (1988), "Communication and control processes in the delivery of 
service quality", Fournal of Marketing, Vol. 52 No. 2, pp. 35-48.

Zeithaml, V.A., Parasuraman, A. and Berry, L.L. (1985), "Problems and strategies in services marketing", fournal of Marketing, Vol. 49 No. 2, pp. 33-46.

\section{Further reading}

Bitner, M.J., Booms, B.H. and Tetrault, M.S. (1990), "The service encounter: diagnosing favourable and unfavourable incidents", fournal of Marketing, Vol. 54 No. 1, pp. 71-84.

Journal of Service Research (2015), "Special issue on transformative service research", Vol. 18, No. 3.

Journal of Service Research (2018), "Special issue on service design”, Vol. 21, No. 1.
Marketing renaissance: opportunities and imperatives for improving marketing thought, practice, and infrastructure (2005), fournal of Marketing, Vol. 69, pp. 1-25.

\section{About the author}

Christian Grönroos is a Professor Emeritus of Service and Relationship Marketing at Hanken School of Economics, Finland. $\mathrm{He}$ is a pioneer developing the academic field of service marketing and Co-founder of the Nordic School of Service Marketing Research. He has published extensively on service marketing and service management topics. His most recent activity is a set of short video lectures on "Principles of Service Management" on YouTube. In 2013 he was selected Legend in Marketing by the Sheth Foundation. Christian Grönroos can be contacted at: christian.gronroos@hanken.fi 